\title{
Editorial: Theology and the environment
}

The theme of this issue of Theology in Scotland will be no surprise. With COP26 taking place in Glasgow this November, many initiatives have emerged, offering ideas and action points to address the climate crisis our planet is currently facing. Our hope as co-editors of this issue is that it will be a meaningful and helpful contribution to whatever else our readers are hearing, seeing, contemplating, or being involved in.

It will also be of no surprise that as those involved in theological study and ministry, we see theological questions as essential in truly understanding and tackling the current crisis. Yet at this point we must also note that ecology and Christian faith have a complex relationship historically. A disturbing proportion of professing Christians across the world still doubt the very fact that the current climate emergency has much to do with human activity, or that climate justice is an urgent theological and missional concern. They would also vehemently disagree with the claim that today's ecological concerns have much to do with an exploitative type of theology which sees the Earth in a subservient relationship to humans: an accusation expressed by the famous address-turned-lecture of the historian Lynn White, more than half a century ago. ${ }^{1}$

Many debates have taken place since, and many other theological voices have, in one way or another, continued to challenge the anthropocentric worldview as something that does not represent a faithful reading of Scripture, nor an ethic that can be called truly Christian. In this issue, we celebrate and re-engage with one of these voices: Richard Bauckham, who for a number of years served as the Professor of New Testament Studies and Bishop Wardlaw Professor in the University of St Andrews. His insights into green theology and the cosmic scope of salvation are well worth revisiting. In this issue, he is in conversation with Pat Bennett, a Glasgow-based liturgist and writer. We hope that readers will find this dialogue stimulating and inspiring.

A journal such as this is not likely to convince a climate crisis doubter, but it does highlight the need to acknowledge the complex, and at times

${ }^{1}$ Published as Lynn White, Jr., "The Historical Roots of Our Ecological Crisis", Science 155, no. 3767 (10 March 1967): 1203-1207. 


\section{Editorial}

self-contradictory, ways humans relate the reality around them to their own faith aspirations. This is also true for communities which in principle recognise multiple, human-made environmental crises besetting our planet today, yet still struggle to incorporate this recognition into their own faith practice. This is highlighted by Graeme McMeekin, who in his article points out the dissonance between young people's environmental and justice concerns, and the lack of sufficient interest in the ecological aspects of Christian witness in Scottish evangelical circles. His article is a reminder that language matters enormously - as illustrated by the tensions even around the terminology used to describe the current ecological challenge. McMeekin, who is Head of Tearfund Scotland, explores the anthropological lens through which evangelicals tend to view the created world, and suggests a pragmatic response in terms of the kind of images and language that would naturally speak and relate to evangelical believers.

Whilst today's adults may argue about the impact of climate crisis, it is the next generation that will bear the brunt of ecological disasters caused by human mismanagement of natural resources today. In her article, Robyn Boeré, Associate Lecturer in Christian Ethics at the University of St Andrews, links up theology, environmental concerns and ethics concerning children. As she notes, children rarely feature in theological discussions, are often marginalised even in ecological considerations, and are certainly absent in policy discussions. Going far beyond the fundamental duty of care for the children and the protection of their future, Boeré contends that there is much to be learned from the way children engage with the natural world when given the chance. She considers what it might mean to become like children in relationship to God, and rather than turning to the countryside as the locus of ecological inspiration, is intent on a creative greening of urban landscapes, offering a number of helpful pointers for reimagining, and transforming, the city.

The city also represents a particular challenge in another essential aspect of human life: namely, work. In his article, Stuart Weir, an independent scholar, offers a proposal for a spirituality of work that takes its inspiration and guidance from the Shema, 'the greatest commandment'. Drawing attention to the Hebraic holism and its incorporation of the physical expression of loving God (with all one's 'might' or 'strength'), Weir calls for a 'somatic revival' of human work. He expresses deep concern about the harmful effects of the sedentary working conditions that 


\section{Editorial}

have come to characterise a great proportion of the workforce of today's Scotland, and the extent to which it is enforced by the capitalist market. At a time when, following the pandemic, half or more of UK workers are seriously considering a career change, these are indeed important and exciting questions to explore. ${ }^{2}$

What, then, lies beyond COP26? In her review essay, Anna Fisk, theologian and climate justice activist, reflects on theological tools for the climate justice movement in conversation with five recent books: Catherine Keller's Facing Apocalypse; Thomas Lynch's Apocalyptic Political Theology; Alastair McIntosh's Riders on the Storm; Hannah Malcolm's edited volume Words for a Dying World; and Frances Ward's Like There's No Tomorrow.

This issue of Theology in Scotland also contains a new section on arts and culture, which we hope will have a regular appearance in the journal, featuring creative work of Scottish artists, theologians and practitioners of faith. On this occasion, Jock Stein, a Church of Scotland minister who took up writing poetry in his retirement, shares two poems which speak of his own hopes for COP26 and beyond.

All of these contributions cover a number of significant areas of work in responding to the crisis the world faces. They also point to intricate and at times surprising connections between these areas, and the importance of integrating our care for environment into our own spirituality and our everyday living as well as into our social engagement, theological propositions or scientific arguments. Our hope is that readers will also find such connections stimulating, challenging, and hope-full.

\section{Lina Toth and Doug Gay}

\footnotetext{
${ }^{2}$ See, for instance, "How the Great Resignation Will Shape HR and the Future of Work", Workhuman, https://www.workhuman.com/resources/research-reports/ how-the-great-resignation-will-shape-hr-and-the-future-of-work; Aviva executive report, How We Live: April 2021, 27-31 https://www.aviva.co.uk/content/dam/aviva -public/gb/pdfs/personal/news-and-guides/in-the-news/how-we-live/how-we-live -executive-report.pdf. The phenomenon is not limited to the United Kingdom: see, e.g., Josie Cox, "How Workers Are Re-defining Professional Ambition", BBC Worklife, https://www.bbc.com/worklife/article/20210906-are-we-becoming-lessambitious. (All sources accessed 18 September 2021.)
}

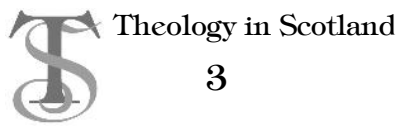




\section{Editorial}

\section{A word of introduction from the Editor, Dr Lina Toth}

In the previous issue, we marked the retirement of Ian Maxwell from the editorship of Theology in Scotland, thanking him for twelve years of faithful service. As I am taking over from Ian, a few words of introduction are in order, both for those who have been reading the journal for many years, and for those who have only just discovered Theology in Scotland, perhaps since it has become freely available online.

I hail from Lithuania (although when I was born it was still part of the USSR), and before coming to Scotland I worked and lived in Prague, Czechia, where for a number of years I was engaged in international theological education. This instilled in me a deep love for different cultural expressions of faith, as well as attentiveness to diverse, multi-disciplinary approaches to doing theology.

I am Assistant Principal and Lecturer in Practical Theology at the Scottish Baptist College, University of the West of Scotland, and Senior Research Fellow at the International Baptist Theological Study Centre based in The Netherlands. As a theologian, I have also been increasingly drawn to history - not so much dates, but people and stories which have shaped the world we live in today. My interests in ethics, culture, and history are the inspiration behind my newest book, Singleness and Marriage after Christendom: Being and Doing Family (Eugene, Or.: Cascade Books, 2021).

Perhaps because Scotland is my adopted home (and what a welcoming one!), I feel especially honoured by this invitation to edit a journal that is titled Theology in Scotland. I hope it continues to be a space for stimulating conversations across the theological spectrum, drawing from the riches of the Scottish theological tradition and welcoming new insights that can deepen contemporary theological thought and practice, particularly in Scotland but also beyond.

\section{Date for your diary: D. W. D. Shaw lecture}

Prof Paul Fiddes (University of Oxford) will give the first in an annual series of lectures honouring Theology in Scotland's founding editor, Prof Bill Shaw. The lecture, on theology and the imagination, will take place on 9 February 2022 at 5pm in New College, Edinburgh. (Further details will be announced on our website and via social media.) 